\title{
Correlates of Political Participation
}

\author{
JOHN WAYNE V. JACINTO \\ Associate Professor I, Jose Rizal Memorial State University \\ Email: jacintojohnwayne89@gmail.com
}

\begin{abstract}
The purpose of this study is to find out the factors related to the political participation of teaching and nonteaching staff of Jose Rizal Memorial State University-Main Campus, Dapitan City. This study employed the descriptive-correlational method of research through a survey questionnaire administered among the 32 randomly selected respondents. The correlates of political participation explored were the profile of the respondents, political trust, political interest, political efficacy, media usage and social networking site use. The study found out that the respondents often have political trust in the selected government institutions, generally somewhat interested in politics, agree to have political efficacy, and disagree to have political participation. In terms of media usage, they sometimes used them and rarely used social networking sites. In the context of this study, political participation is a choice and it is not selective of age, occupation, income, civil status, and location of residence. Regardless of one's demographic profile, participation in politics is so common especially in this democratic country where almost everyone has a say and entitled to express his/her wanted reforms as long as within the ambit of his/her rights. Being politically trustful and interested have moderate tendency of dictating one's political participation. Political efficacy can go with the extent of political participation. Likewise, exposure to SNS for obtaining politically-based information can drive along with political participation.
\end{abstract}

Keywords: Political Participation, Academe, Social Networking Sites, Politics.

\section{Introduction}

Political participation is one of the major characteristics of democracy. With the ever-changing society, there is an expansion of the available forms of participation which placed a problem in its conceptualization as there are new modes of participation (van Deth, 2016). Thus, political participation is not stationary, it is very dynamic (Riley et al. 2010 as cited in Lamprianou, 2013). Moving away from traditional politics and integrating new forms of political participation made this transformation which included almost every activity to be politically related. Conventionally, it refers to voluntary activities by which members of a society, directly and indirectly, influence the selection of leaders and formation of public policy (Gale, 2008). Some of the obvious examples of these activities include voting, attendance at meetings and communicating with representatives and more actively, the membership to a political party and joining campaigns. On the other hand, unconventional activities are those that challenge and defy established institutions and norms.

In the Philippine history, political participation runs from writing novels which criticized political leaders as in the case of Dr. Jose P. Rizal, secret insurgency movement by revolutionary leaders [such as Bonifacio, Jacinto, and Aguinaldo].Guerrilla fighting during American regime also showed Filipinos' behaviors against political leaders in the country. During President Marcos' dictatorship, youth activists made antidictatorship movement and street demonstrations and later on to People Power of 1986 which ousted him in public office. Likewise, People Power II led to the downfall of President Estrada (Velasco, 2001).Today, 
participation already stretched from older practices of face-to-face activities to virtual means on the internet (Schofer \& Fourcade-Gourinchas, 2001 as cited in Xinzhi Zhang and Wan-Ying Lin, 2014). They provide people a wider array of choices in joining politically-related discussions through blogs, social networking sites and even informing the public regarding political issues in the country.

Political participation varies from the kind of government and the nature of societies and it changes as people become more aware of their political rights. There are factors which influenced and led to these variations. Some of the factors that determine political participation are cultural, economic, political, religious and educational backgrounds of individuals. Also, the level of political awareness and the measure of confidence in the political process, determine the extent to which the citizens participate in the political system (Falade, 2014). In the study of Sucgang (2006), she identified that political engagement could be influenced by social structural-demographic and attitudinal. Social structural-demographic would include age, civil status, education, socioeconomic status, sex, race, locale or type of community, and membership in organizations or political parties. Conversely, attitudinal variable comprised of political efficacy, political interest, and political trust.

Despite advent of social networking sites and media, studies exploring their possible effects on political participation were only a few particularly in the Philippines. Exploring these variables can enhance Filipino's understanding as to how political participation has changed over time especially in some of the depressed communities in the country. Colleges and Universities as sources of knowledge in the community played a crucial role in educating their constituents on the significance of their political participation. Professors from these institutions made speeches and presentations and even organized conferences in order to provide Filipinos the avenues to express their political interests. The rampant use of social networking sites and electronic media made politically-related information more accessible.

The accessibility of politically-related information is a factor creating a more knowledgeable people who may become politically active. It is said that people in the academe particularly faculty should not be politically biased (CSC MC No. 30 s. 2009). Despite this, they can still manifest their political participation through voting as long as it does not influence their students and affect their functions and duties. How do these people in the academe participate politically is one of the manifestations of their desires to actively engage in choosing the right people for public positions. As knowledgeable members of the community, they can serve as guides in leading students to right choices and to proper political participation.

But with the advent of electronic media and internet, were these people still politically active? It is interesting to know how these people in the academe, especially in one of the poorest provinces in the Philippines like Zamboanga del Norte (Sabornido, 2015), participate politically. Jose Rizal Memorial State University (JRMSU) is the only university in Zamboanga del Norte. As an institution of higher learning, its teaching and non-teaching staff have become agents who can give its constituents in different communities a clearer view on how should the province be governed and in what way it is influenced by their political participation. With their crucial role in communities, are they too politically active? What factors then are related to their political participation? Are they still influenced by their socio-demographic profile and attitude politically? Do social networking sites which provide accessible information influence their participation?

\section{Objectives}

This study aimed to determine the following:

1. The extent of political participation among the teaching and non-teaching staff of JRMSU;

2. The socio-demographic and attitudinal factors which may be correlated with the political participation of teaching and non-teaching staff of JRMSU; and

3. The possible relationship of media and social networking sites use to political participation. 


\section{Research Methodology}

The study used the descriptive-correlational method of research with the aid of survey questionnaire in which some of its main parts were adopted and modified from the study of Xinzhi Zhang \& Wan-Ying Lin (2014). The questionnaire had 7 parts as discussed in the following:

\section{Profile of the Respondents}

This part consisted of age, sex, occupation, monthly income (six brackets with PhP. 6000.00 interval from PhP. 6,000.00 and below to PhP. 30,001.00 and above), home location (urban and rural), highest educational attainment, and civil status. The backgrounds of the respondents were determined and correlated against political participation.

\section{Political Trust}

This part presented the different government institutions such as national (central) government, the provincial government, local government, Philippine Senate, Philippine Congress, Armed Forces of the Government, Philippine National Police, and Department of Justice. These institutions were rated as to how often the respondents trusted them using a five-point Likert scale ranging from never to always (Cronbach's $\alpha=0.6640$ ).

\section{Political Interest}

It was comprised of 3 general questions on: (1) general interest in politics, (2) interest in the 2016 National Election; and (3) how often politics was thought (Cronbach's $\alpha=0.8501$ ). The first two questions were measured using a 5-point Likert scale ranging from don't know/no answer to very interested while the last one ranged from not even once to always.

\section{Political Efficacy}
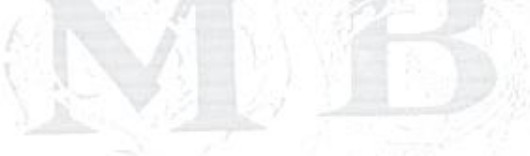

The statements for political efficacy (internal) were adopted from the study of Xinzhi Zhang \& Wan-Ying Lin (2014). Some of the items were modified in order to fit with the context of the study. The original was composed of 4 statements but this study added one question in terms of how knowledgeable were the respondents on the significant effect of their votes. Each statement was quantified using a 5-point Likert scale ranging from strongly disagree to strongly agree in order to determine the extent to which they agree on possessing the characteristics described in each statement (Cronbach's $\alpha=0.7937$ ).

\section{Political Participation}

Some of the items in political participation were modified for suitability in the research environment. It was consisted of 11 items and Xinzhi Zhang \& Wan-Ying Lin (2014) categorized these items into the canonical mode of participation, contacting/lobbying mode of participation and involvement in political partyinitiated participation. These three modes were adopted as they were suitable for the study. Although there were many modes, but they could be generally grouped in these 3 categories.

The canonical mode here referred to those political activities done for the benefit of the many while the contacting/lobbying mode was done for personal and private interest. On the other hand, the political partyinitiated participation dealt with those activities led by one's party membership such as campaigns, meetings, and sometimes being a candidate. Each item was measured in terms of how often respondents participate in such activity using a 5-point Likert scale with descriptions from never to always (Cronbach's $\alpha=0.8823$ ). 


\section{Media Usage}

This part contained the items on media usage - traditional and electronic and categorized into news media use, interpersonal media use, and recreational media use. Each item was measured as to how often respondents applied such media use ranging from never to always using a 5-point Likert scale.

\section{Social Networking Sites Use}

This last part of the questionnaire dealt with how respondents being in a technological world used social networking sites (SNS) in order to express their political ideas. The items in this part were categorized into: (1) information exchange and instrumental uses; (2) social networking use; (3) recreational and entertainment uses; and (4) SNS-based political activities.

The questionnaire was administered to the 32 randomly selected-respondents of Jose Rizal Memorial State University-Main Campus, Dapitan City. Each respondent was given enough time to answer each part and assured of the confidentiality of his/her responses.

These respondents were comprised of $65.62 \%$ teaching and $34.38 \%$ non-teaching personnel. Majority of these respondents $(31.25 \%)$ belonged to the age bracket of $21-25$ years old and mostly female $(62.5 \%)$. About $34.38 \%$ had salary ranging PHP. 18,001.00-PHP. 24,000.00 and more than 70\% lived in urban areas. In terms of education, $43.75 \%$ revealed that they completed graduate studies followed by those who attended graduate studies (37.5\%) and 50\% were married.

The statistical tools used were the (1) frequency count for profile of the respondents; (2) weighted mean in determining the extent of political trust, political interest, political efficacy, political participation, media usage, and social networking sites use; (3) Mann-Whitney U Test and Kruskal-Wallis Test in testing the differences among responses when grouped as to respondents' profile; and (4) Spearman Rank Correlation Coefficient for the relationship between political participation and selected factors.

\section{Results}

\section{Political Trust}

Table 1 below shows the government institutions tested against the extent of trust gained from the respondents. One may suggest that lack of political trust may lead to political apathy or could lead to active engagement in order to effect change in the political system. As can be gleaned in the table, respondents do not always trust any of the government institutions rather they just often trusted them as a whole.

Table 1 How Often Government Institutions Gain Political Trust

\begin{tabular}{|l|c|c|}
\hline Government Institutions & Mean & Verbal Description \\
\hline National (Central) Government & 3.875 & Often \\
\hline Provincial government & 3.313 & Sometimes \\
\hline Local Government & 3.563 & Often \\
\hline Philippine Senate & 3.219 & Sometimes \\
\hline Philippine Congress & 3.313 & Sometimes \\
\hline Armed Forces of the Philippines & 3.844 & Often \\
\hline Philippine National Police & 3.281 & Sometimes \\
\hline Department of Justice & 3.344 & Sometimes \\
\hline Average Weighted Value & 3.469 & Often \\
\hline
\end{tabular}

Although, Philippine Senate got the lowest mean of 3.219 it was still described as sometimes. Among the institutions, National or Central Government was rated the highest with a mean of 3.875 and described as 
often same with local government and AFP. The second lowest rating was on PNP (3.281). Despite the campaign of General Ronald de la Rosa of cleansing all police officers.

\section{Political Interest}

Interest in politics is a desire to participate, yet it does not necessarily equate to actual involvement. It is very crucial for a democratic society to maintain the ideals of democracy. Generally, the respondents have somewhat interest (3.656) in politics and it can be attributed that they only thought of it sometimes (3.375). They were only very interested in the 2016 National Election (4.219) as the country is moving towards new administration.

Table 2 Extent of Political Interest

\begin{tabular}{|l|c|c|}
\hline Political Interest & Mean & Verbal Description \\
\hline General Interest in Politics & 3.656 & Somewhat Interested \\
\hline Interest During the 2016 National Election & 4.219 & Very Interested \\
\hline How Often Politics is Thought & 3.375 & Sometimes \\
\hline
\end{tabular}

\section{Political Efficacy}

A feeling that everyone has a significant role to play in bringing political change is having political efficacy (Campbell, Gurin, and Miller, 1954, p. 187 as cited in Schulz, W., 2005). If everyone has the realization that he/she could bring changes in one's society politically, then participation is expected. Having all respondents strongly agree (4.531) that their individual vote has a significant effect in choosing government leaders is no surprise as for decades living in a democratic country it is always being emphasized as a right and freedom. The respondents being in the academe are undecided as being wellqualified to participate in politics (3.063) however, they agree to be as good as most people in public office (3.969) for they agree to have been informed and have an understanding of political issues (3.625 and 3.406 respectively).

Table 3 Extent of Agreement on Political Efficacy

\begin{tabular}{|l|c|c|}
\hline Political Efficacy & Mean & \\
\hline $\begin{array}{l}\text { "I know that my vote together with other voters can have a } \\
\text { significant effect in determining government leaders. }\end{array}$ & 4.531 & Strongly Agree \\
\hline $\begin{array}{l}\text { "I feel that I could do as good a job in public office as most } \\
\text { other people," }\end{array}$ & 3.969 & Agree \\
\hline "I consider myself well-qualified to participate in politics," & 3.063 & Undecided \\
\hline $\begin{array}{l}\text { "I feel that I have a pretty good understanding of the } \\
\text { important political issues facing our locality and country as a } \\
\text { whole," and }\end{array}$ & 3.625 & Agree \\
\hline $\begin{array}{l}\text { "I think that I am as well-informed about politics and } \\
\text { government as most people". }\end{array}$ & 3.406 & Agree \\
\hline Average Weighted Value & 3.719 & Agree \\
\hline
\end{tabular}

\section{Political Participation}

With the three modes of political participation, the respondents showed in Table 4 that they generally disagree to admit to be participating in politics. In terms of canonical mode of participation, the respondents indicated that they agree to follow news on politics (3.906) but are not active in pushing any political issue or problem due to refusal in singing petition letters, joining demonstrations and contacting official media (1.656, 1.406 and 1.344 respectively). As a whole, they disagree to be participating in any of these political activities and further supported by the result that, being in the academe, they strongly disagree to be participating especially those activities initiated by political parties (1.688). They could not 
even say that they were contacting or lobbying political leaders for personal interest (2.648). They only agree to participate in politics through following the news regularly and expressing their opinions to students, faculty or officemates (3.906 and 3.406 respectfully) but in terms of specifically discussing politics with friends or colleagues, they could not decide their participation (3.250). Overall, the respondents disagree to be participating in activities politically.

Table 4 Extent of Agreement on Different Modes of Political Participation

\begin{tabular}{|l|c|c|}
\hline Modes of Political Participation & Mean & Verbal Description \\
\hline Canonical Mode of Political Participation & & \\
\hline Follow news on government or politics regularly & 3.906 & Agree \\
\hline Discuss politics with friends or colleagues & 3.250 & Undecided \\
\hline Sign petition letters & 1.656 & Strongly Disagree \\
\hline Join demonstrations that are not organized by party officials & 1.406 & Strongly Disagree \\
\hline Contact official media to cover the event & 1.344 & Strongly Disagree \\
\hline Average Weighted Value & $\mathbf{2 . 3 1 2}$ & Disagree \\
\hline Contacting/Lobbying Mode of Participation & & Agree \\
\hline Express opinions to students, faculty or officemates & 3.406 & Undecided \\
\hline Seek help from higher officials at the University & 2.875 & Disagree \\
\hline Lobby with acquaintances of political leaders & 2.094 & Disagree \\
\hline Seek help directly from higher-level government personnel & 2.219 & Undecided \\
\hline Average Weighted Value & $\mathbf{2 . 6 4 8}$ & Disagree \\
\hline Political Party-Initiated Participation & & Strongly Disagree \\
\hline $\begin{array}{l}\text { Attend political campaigns/meetings/learning sessions } \\
\text { organized by one's political party-related institutions }\end{array}$ & 2.094 & \\
\hline $\begin{array}{l}\text { Become candidate in one's political party or government- } \\
\text { related elections }\end{array}$ & 1.281 & Strongly Disagree \\
\hline Average Weighted Value & $\mathbf{1 . 6 8 8}$ & Disagree \\
\hline Overall Average Weighted Value & $\mathbf{2 . 2 1 6}$ & \\
\hline
\end{tabular}

\section{The Extent of Media Use}

Media use can be a source of a lot of information including politically related that can strengthen people's understanding of issues concerning society. The table below presents the summary of respondents' responses on the use of media (traditional and electronic). The respondents are often (3.500) using media as sources of news like watching TV, viewing news, reading newspapers, and reading online text news. It is interesting quite that even in a world of apps for recreation, these respondents put priority on using media to better understand political issues through news than for interpersonal use (3.359) like watching nonpolitical online videos, sending emails and making instant messaging and phone calls which they sometimes manifest similar with recreational media use (2.756) which involves reading books and using mobile apps.

Table 5 The Extent of Media Use

\begin{tabular}{|l|c|c|}
\hline Media Use & Mean & Verbal Description \\
\hline News Media Use & 3.500 & Often \\
\hline Interpersonal Media Use & 3.359 & Sometimes \\
\hline Recreational Media Use & 2.756 & Sometimes \\
\hline Average Weighted Value & $\mathbf{3 . 2 0 5}$ & Sometimes \\
\hline
\end{tabular}




\section{The Extent of Social Networking Sites Use}

The advent of the internet makes distance and time irrelevant. Political information can be accessed in seconds, thus discussions regarding political issues swarmed people anywhere in the country through their SNS accounts. Being ignorant of political issues may seem impossible as long as access to SNS is within reach. The table below shows the summary as to how often respondents were using SNS. The results of media use are quite different from the respondents' use of SNS. All usages of SNS as indicated below that are politically related are rarely manifested or used specifically on information exchange and instrumental uses and SNS-based political activities (2.307 and 1.922 respectively). Only those usages related to making friends and discussions outside of politics lie social networking uses and recreational and entertainment uses are rated sometimes (2.994 and 3.094 respectively).

Table 6 Extent of Social Networking Sites Use

\begin{tabular}{|l|c|c|}
\hline Social Networking Sites (SNS) Use & Mean & Verbal Description \\
\hline Information exchange and instrumental uses & 2.307 & Rarely \\
\hline Social networking uses & 2.994 & Sometimes \\
\hline Recreational and entertainment uses & 3.094 & Sometimes \\
\hline SNS-based political activities & 1.922 & Rarely \\
\hline Average Weighted Value & $\mathbf{2 . 5 7 9}$ & Rarely \\
\hline
\end{tabular}

\section{Test of Significant Difference on Political Participation}

Table 7 Test of Significant Difference on Political Participation When Analyzed as to Age, Income, Highest Educational Attainment, Civil Status, Sex, Occupation and Location

\begin{tabular}{|l|c|c|c|}
\hline \multicolumn{1}{|c|}{ Factors } & Computed W-value & Computed H-value & p-value \\
\hline Age & & 6.95 & $0.435^{\mathrm{ns}}$ \\
\hline Income & & 2.10 & $0.552^{\text {ns }}$ \\
\hline Educational Attainment & & 4.81 & $0.186^{\text {ns }}$ \\
\hline Civil Status & & 3.62 & $0.164^{\text {ns }}$ \\
\hline Sex & 217 & & $0.4715^{\text {ns }}$ \\
\hline Occupation & 194 & & $0.6340^{\mathrm{ns}}$ \\
\hline Location & 399.5 & & $0.5688^{\mathrm{ns}}$ \\
\hline
\end{tabular}

ns $=$ not significant at $\mathrm{p}>0.05 \quad *=$ Significant at $\mathrm{p} \leq 0.05$

Table 7 above shows that the extent of political participation of the respondents does not differ regardless of their age, income, highest educational attainment, and civil status as evidenced in the p-values that are above the 0.05 level of significance $(0.435,0.552,0.186$, and 0.164 respectively).

Furthermore, the extent of their political participation does not vary as well even when grouped according to their sex, occupation, and location as supported by the p-values that are above the 0.05 level of significance $(0.4715,0.6340$, and 0.5688 respectively).

\section{Test of Significant Relationships on Political Participation}

Table 8 Test of Significant Relationship Between Political Trust and Political Participation

\begin{tabular}{|l|c|c|c|c|}
\hline \multicolumn{1}{|c|}{ Factors } & Means & Computed $\rho$ & P-values & Interpretation \\
\hline Political Trust & 3.469 & 0.554 & $0.001^{*}$ & $\begin{array}{c}\text { Moderate correlation } \\
\text { Significant relationship }\end{array}$ \\
\hline Political Participation & 2.321 & & &
\end{tabular}

ns $=$ not significant at $\mathrm{p}>0.05 \quad *=$ Significant at $\mathrm{p} \leq 0.05$ 


\section{Test of significant relationship between political trust and political participation}

The table above clearly depicts that political trust is positively and moderately correlated to political participation $(\rho=0.554)$. With a p-value of 0.001 which is lower than the 0.05 level of significance, the relationship is really significant. It implies that despite its moderate correlation, it is significant. Further, the positive correlation denotes a direct relationship which signifies that as the level of political trust becomes higher, then the extent of political participation increases.

Table 9 Test of Significant Relationship Between Political Interest and Political Participation

\begin{tabular}{|l|c|c|c|c|}
\hline \multicolumn{1}{|c|}{ Factors } & Means & Computed $\boldsymbol{\rho}$ & P-values & Interpretation \\
\hline Political Interest & 3.375 & 0.417 & $0.017^{*}$ & $\begin{array}{c}\text { Moderate correlation } \\
\text { Significant relationship }\end{array}$ \\
\hline Political Participation & 2.321 & &
\end{tabular}

ns $=$ not significant at $\mathrm{p}>0.05 *=$ Significant at $\mathrm{p} \leq 0.05$

\section{Test of significant relationship between political interest and political participation}

Based on the table above, political interest is moderately correlated to political participation having a $\rho$ value of 0.417 . This moderate correlation is significant as shown with a p-value of 0.017 which is still lower than the 0.05 level of significance. Since the value of $\rho$ is positive it indicates a direct relationship where an increase in the respondents' political interest will also increase the extent of political participation.

Table 10 Test of Significant Relationship Between Political Efficacy and Political Participation

\begin{tabular}{|l|c|c|c|l|}
\hline \multicolumn{1}{|c|}{ Factors } & Means & Computed $\boldsymbol{\rho}$ & P-values & \multicolumn{1}{|c|}{ Interpretation } \\
\hline Political Efficacy & 3.719 & 0.688 & $0.000^{*}$ & $\begin{array}{l}\text { Strong correlation } \\
\text { Significant relationship }\end{array}$ \\
\hline Political Participation & 2.321 & & &
\end{tabular}

ns $=$ not significant at $p>0.05 *=$ Significant at $\mathrm{p} \leq 0.05$

Test of significant relationship between political efficacy and political participation. Table 10 displays the relationship between political efficacy and political participation which is interpreted as strong correlation as proven by $\rho$ value of 0.688 . The p-value of 0.000 signifies the relationship being significant at 0.05 level of significance.

Table 11 Test of Significant Relationship Between Media Usage and Political Participation

\begin{tabular}{|c|c|c|c|c|}
\hline Factors & Means & Computed $\rho$ & P-values & Interpretation \\
\hline News Media Use & 3.500 & \multirow{2}{*}{0.386} & \multirow{2}{*}{$0.029^{*}$} & Weak correlation \\
\hline Political Participation & 2.321 & & & Significant relationship \\
\hline Interpersonal Media Use & 3.359 & \multirow{2}{*}{0.411} & \multirow{2}{*}{$0.020^{*}$} & Weak correlation \\
\hline Political Participation & 2.321 & & & Significant relationship \\
\hline Recreational Media Use & 2.756 & \multirow{2}{*}{0.389} & \multirow{2}{*}{$0.028^{*}$} & Weak correlation \\
\hline Political Participation & 2.321 & & & Significant relationship \\
\hline
\end{tabular}

$\mathrm{ns}=$ not significant at $\mathrm{p}>0.05 *=$ Significant at $\mathrm{p} \leq 0.05$

\section{Test of significant relationship between media use and political participation}

Exposure to media can open avenues for information dissemination particular political matters. With this information, people will have a clearer idea on how one should participate in a political activity. As can be gleaned in Table 11, the use of media for the purposes of news, interpersonal and recreation are weakly correlated with political participation as revealed in $\rho$ values of $0.386,0.411$ and 0.389 respectively. Although the relationship is slight it is significant (p-values 0.029, 0.020 and 0.028). 
Table 12 Test of Significant Relationship Between Social Networking Sites Use and Political Participation

\begin{tabular}{|c|c|c|c|c|}
\hline Factors & Means & Computed $\rho$ & P-values & Interpretation \\
\hline $\begin{array}{l}\text { Information exchange and } \\
\text { instrumental uses }\end{array}$ & 2.307 & \multirow[t]{2}{*}{0.589} & \multirow[t]{2}{*}{$0.000^{*}$} & \multirow[t]{2}{*}{$\begin{array}{l}\text { Moderate correlation } \\
\text { Significant relationship }\end{array}$} \\
\hline Political Participation & 2.321 & & & \\
\hline Social networking uses & 2.994 & \multirow{2}{*}{0.505} & \multirow{2}{*}{$0.003^{*}$} & \multirow{2}{*}{$\begin{array}{l}\text { Moderate correlation } \\
\text { Significant relationship }\end{array}$} \\
\hline Political Participation & 2.321 & & & \\
\hline $\begin{array}{l}\text { Recreational and } \\
\text { entertainment uses }\end{array}$ & 3.094 & \multirow[t]{2}{*}{0.219} & \multirow[t]{2}{*}{$0.228^{\text {ns }}$} & \multirow{2}{*}{$\begin{array}{l}\text { Weak correlation } \\
\text { No significant } \\
\text { relationship }\end{array}$} \\
\hline Political Participation & 2.321 & & & \\
\hline $\begin{array}{l}\text { SNS-based political } \\
\text { activities }\end{array}$ & 1.922 & \multirow[t]{2}{*}{0.721} & \multirow[t]{2}{*}{$0.000^{*}$} & \multirow[t]{2}{*}{$\begin{array}{c}\text { Strong correlation } \\
\text { Significant relationship }\end{array}$} \\
\hline Political Participation & 2.321 & & & \\
\hline
\end{tabular}

$\mathrm{ns}=$ not significant at $\mathrm{p}>0.05 *=$ Significant at $\mathrm{p} \leq 0.05$

\section{Test of significant relationship between social networking sites and political participation}

The table above presents that among the dimensions or categories of SNS use, only recreational and entertainment uses has a weak correlation ( $\rho$-value -0.219$)$ but not significant $(\rho$-value -0.228$)$. The result is contradictory on the use of media for recreation. The use of SNS for information exchange and instrumental and social networking have a moderate relationship with political participation ( $\rho$-values 0.589 and 0.505$)$ and it is significant as all the p-values are lower than 0.05 level of significance. However, the correlation is strong between SNS-based political activities and political participation ( $\rho$-value - 0.721).

\section{Discussions}

The teaching and non-teaching staff of Jose Rizal Memorial State University, Dapitan City, Philippines did not always guarantee their full trust on different government institutions. For the past years, some of the programs of the government were not fully implemented due to changes in political administration coupled with news swarmed in televisions on corruption in the government have really changed the way these people view government. In a survey conducted in 2014 Philippine Trust Index subtitled "Understanding the trust landscape In the Philippines", it revealed that among the six institutions (Church, academe, media, government, non-government organizations and business), the government got the least trust among Filipinos (Makabenta, Y., 2014). In the study, the second least trusted government institution based on the rating was Philippine National Police despite the campaign of General Ronald de la Rosa of cleansing all police officers. This is really a threat to the peace and order if people do not fully trust the implementers of laws since valuable information or illegal activities may not be transmitted to higher authorities especially police officers. But the Armed Forces of the Philippines (AFP) gained trust often among the respondents as Zamboanga del Norte was repeatedly pronounced by the military as peaceful (Laput, 2015) compared to other provinces. The AFP's are the ones whom people can rely on and capable of protecting them second to their prayers especially when the crisis in war broke-out. Even the justice system was not fully and always trusted by the respondents. This can be attributed to the idea of the delayed justice system in the Philippines where until now these people sometimes doubt its capabilities of sending culprits to jail. According to Villarama, Jr., M. (2017), one of a characteristic of Filipinos is procrastination. This characteristic is translated to their inefficiency in government violating Anti-Red Tape Act where the judiciary is no exception. Trust in any government institution is a prerequisite to the development of society and the survival of political system (Miller, 1974 as cited in van der Meer, T.W.G. 2017). Dissatisfaction with government services really declines people's trust. With no trust in political leaders, particularly in local and provincial government can gain no support from people and may lead to political apathy by disregarding their significant role in improving the political system. The worst scenario is that they may be forced to become activists trying to resist and defile the government. Without full trust in national and local government forces some people stop pursuing political changes as it becomes useless, thus curbing down 
their political interest. As for this reason, trust should always be secured among people for the survival of a political system and strong governance. Further, with the presence of trust, people are confident that their interest will be accommodated regardless of the extent of monitoring and evaluation done among public officials (van der Meer, T.W.G. 2017). However, there will still be people who lack the political trust due to the experiences related to their unfulfilled interests and needs. This is true in any democratic country where the government cannot actually satisfy individual's interest as needs vary from persons and sometimes they contradict with government policies, thus gaining full trust is a challenge (Dalton, R.J., 2016).

The respondents being in a democratic country agreed on having political efficacy. The decades of experience on free public elections and political freedom strengthened their support for a democratic political system as they have a say in any in political policies. Their knowledge and understanding of politics and being aware of different political issues in the locality and country as a whole let them feel that as an individual, they can influence political decisions and policies. It even made them agree that they can too become a good public servant but still doubtful on their qualification to run for public office. Despite few restrictions in the country before an individual can run for public office, where most people are qualified, they still have the idea that to become a public servant requires a very strong background and knowledge on politics and governance and have the heart and ability in serving people.

It is a mere fact in public academic institutions that its administration is doing everything in order to maintain quality service delivery. However such objective requires support systems and budgetary assistance the reason that public academic institutions, particularly in basic education, need to maintain a strong and harmonious relationship with the community so as to gain such support (Rubin, M.J., 1952). Some believed that teachers should not be politically involved as it may bring political impact among their students during discussions favoring a certain political leader. Despite this, and due to the pressure from superiors to provide the needs of the academic institution, lobbying or contacting politicians becomes sometimes the best resort. The respondents being in the academe disagreed to be participating politically as a whole. As it is being encouraged that they must be neutral and should not be campaigning their political candidates. With regard to budget and support system, higher academic institutions can be said to have more of these than those in basic education. Thus, employees (teaching and non-teaching staff) were not pressured to personally provide the needs of the students and institution which can put them in a dilemma to eventually participate politically. As a result, these respondents are not really politically active in different modes of political participation. They agreed to be involved in some political activities which are not considered as a radical form participation such as following news on government or politics, expression of opinions to students, faculty or officemates. They were even undecided if they discussed politics with friends or colleagues. Politics is no big deal for them as they are already preoccupied with work-related matters. The political system has never been disturbing their lives the reason that they do not even join a demonstration or sign a petition letters in order to satisfy their needs for political changes or reforms. They are already contented as to how the political system runs. Contacting politicians in order to gain favor has not been extensively done even having directly sought help from them. In other words, these people prioritized other endeavor than being actively involved in politics. They refused to be actively involved in it, as being in politics is a complicated situation.

There is a common notion that the backgrounds of people have something to do with their political participation. One specific is that as individuals grow older, attain higher education and being in a well-off family improved their political participation. Conversely, the results of the study have shown that there are no significant differences in political participation when analyzed as to age, income and educational attainment. In the context of the respondents, it does not guarantee that young people are more politically active than older ones even though they are often perceived to have radical activities. Being highly educated does not significantly differ on political participation with those who attained lower education. So, the breadth of knowledge as being highly educated individuals does not equate to the higher level of political participation. Although it is expected that the more individuals become educated the more they 
pursue their rights and freedom to be involved in society rather than a passive receiver of any political policies, this study pointed out differently. It revealed that those who were at the graduate level have similar extent of participation compared to bachelor's degree holders. Likewise, those in the lower income strata and more vulnerable members of society who were sometimes disregarded, participate in politics similar to those who have more financial capability.

Traditionally, there was less participation among women than men in politics. Women were reported to be less involved in activities like joining political parties and attending demonstrations (Kittilson, M. C., 2016). Yet the study revealed an opposite truth. Although male respondents showed a higher level of participation (2.417) than female respondents (2.264), the difference was not significant (p-value: 0.578). It implies that both male and female respondents participate in political activities alike. It is a common scenario in the Philippines nowadays where Filipino women participate in politics as active as their men counterparts. Moreover, Philippines already had 2 female presidents showing their empowerment. According to CNN Philippines (2016) the country topped in Asia-Pacific nations to narrow the gap between women and men in four key areas monitored by the report: Educational Attainment, Health and Survival, Economic Opportunity and Political Empowerment. As women become aware of their rights equal to men, they already invaded the political realm which is formerly male-dominated. Other factors were also analyzed against political participation such as occupation and location of residence as to urban or rural. The employees of JRMSU being not used to contact or lobby politicians for support, manifested a similar level of political participation when responses were compared between teaching and non-teaching staff. Even the location of residence did not yield disparity between the responses of those in urban and rural areas.

Media and social networking sites can provide avenues for political participation. Participation can be in the form of uploading videos or pictures and even rating a political issue, sharing of opinions or joining online discussions. With technologies, people can be equipped with knowledge and understanding on political issues facing the locality and country, one is entitled to express opinions and pursue changes in a political system. Regardless of the opportunities provided by media and SNS, still the respondents do not usually join and make politics a big deal. They were just involved in low-initiative acts like using media for news viewing and reading online news. But the question still lies on whether the use of these media and SNS, political interest, political trust and political efficacy have bearing with the extent of one's political participation. In the political context of respondents, the usage of media as a source of news and interpersonal use and recreation have a weak positive correlation with the extent of political participation but still significant. With these three usages of media, the study emphasizes that in some points as the respondents become more involved in the use of media they too become more involved in politics. News or information from televisions usually contains political messages that can relate to the respondents' political decision whether to participate or not. The use of media for recreation includes reading books and blogging. Blogging can be a low-cost avenue for political participation. With an internet connection, people can discuss almost anything from personal to political and can encourage even thousands of viewers and commenters. In this case, a wide range of exchange of information takes place and people become aware of certain things which can help them to be involved in actual scenarios.

As the respondents live in a technological sphere, the internet is almost accessible. And social networking sites through internet made it possible for people around the world to meet asynchronously and synchronously. Social networking sites make a more convenient and even low-cost way of connecting with people. As it becomes so common, it created a wide range of discussions and solicits more reactions and comments especially when it comes to politics. With SNS, people become aware even in seconds regarding political issues affecting them. It made them more speculative and even sensitive on political issues, thus making them active to participate politically.

Moreover, aside from the use of media and SNS, political trust, interest, and efficacy are also linked to political participation. There are many contradicting results from different studies cited in Braun, D. and 
Hutter, S. (2016) regarding political trust and political participation. For instance, they cited that many studies revealed that being involved in political activities do not directly relate to political trust. Lack of trust could lead to political participation as people become active in pursuing their desires for political reforms. On the other hand, political efficacy as a feeling that changes in political contexts are possible as individuals have the capability in bringing these changes (Campbell, Gurin, and Miller, 1954 as cited in Schulz, W. 2005) have a direct relationship with political participation. When individuals perceived a high level of political efficacy, they are more likely to be active in politics for they become confident of bringing change in the political system. Further, the higher the level of political efficacy, the greater guarantee there is for a democratic system to survive as people emphasize their rights and freedom to be involved and to influence any political issues. This study showed that political trust and political interest have a moderate positive correlation with political participation and it was found significant. It denotes that respondents' political trust and interest are directly linked with political participation. As they put more trust in different political institutions they become more politically active as they can rely on the capacities of the government institutions in bringing programs for the welfare of the people. Their political interest can also be evident in their political participation. The more they manifest interest in politics, the more they likely to be engaged in political activities. Moreover, their political participation is strengthened as they become more politically active and aware that all their efforts of changing matters and be part of making political policies will be heard and given due recognition.

\section{Conclusions}

In the context of this study, political participation is a choice and it is not selective of age, occupation, income, civil status, and location of residence. Regardless of people's demographic profile, participation in politics is so common especially in a democratic country where almost all have a say and entitled to express their wanted reforms as long as within the ambit of their rights. Being politically trustful and interested have a moderate tendency of dictating one's political participation. The greater the political efficacy can go with the extent of political participation. The diminishing political efficacy (internal) can lead to political apathy. Further, exposure to SNS for obtaining politically-based information can drive along with political participation.

\section{References}

Birikti G/Michael T/Haimanot (2014). An Assessment of Factors Affecting Participation of Women in Management Position: The Case of ethio telecom Company. Addis Ababa University. Retrieved from https://www.pdffiller.com/jsfiller-

desk/?projectId=151714937\&expId=2883\&expBranch=3\#f7b9622353d84af49bcfc3651121ad56

Braun, D. \& Hutter, S. (2016). Political Trust, Extra-representational Participation and the Openness of Political Systems. International Political Science Review, 37(2), 151-165. Retrieved from http://www.gsi.uni-muenchen.de/personen/wiss_mitarbeiter/braun1/texte/political-trust.pdf

CNN Philippine Staff (2016). Philippines tops in closing gender gap in Asia-Pacific. Retrieved from http://cnnphilippines.com/news/2016/10/26/Philippines-tops-in-closing-gender-gap-in-AsiaPacific.html

Dalton, R. J. (2016). Political Trust in North America. Handbook on Political Trust, 375-394. Retrieved from http://www.socsci.uci.edu/ rdalton/archive/Trust2017.pdf

Falade, D. A. (2014). Political Participation in Nigerian Democracy: A Study of Some Selected Local Government Areas in Ondo State, Nigeria. Global Journal of Human Social Science: Political Science, 14(8), 17-23. Retrieved from https://globaljournals.org/GJHSS_Volume14/3-Political-Participation-inNigerian.pdf

Kittilson, M. C. (2016). Gender and Political Behavior. Oxford Research Encyclopedia of Politics. Retrieved from http://politics.oxfordre.com/view/10.1093/acrefore/9780190228637.001.0001/acrefore9780190228637-e-71 
Krauss, M. W. (2015). "The Inequality of Politics: Social Class Rank and Political Participation". IRLE Working Paper No. 120-15. Retrieved from http://irle.berkeley.edu/workingpapers/120-15.pdf

Makabenta, Y. (2014). A government Filipinos do not trust. Retrieved from http://www.manilatimes.net/government-filipinos-trust/139041/

Robertson, F. M. (2009). A Study of Youth Political Participation in Poland and Romania. University College London. Retrieved from http://discovery.ucl.ac.uk/18725/1/18725.pdf

Rubin, M. J. (1952). The Teacher's Role in Politics. Retrieved from http://www.ascd.org/ASCD/pdf/journals/ed_lead/el_195210_rubin.pdf

Schulz, W. (2005). Political Efficacy and Expected Political Participation among Lower and Upper Secondary Students. Australian Council for Educational Research. Retrieved from https://iccs.acer.org/files/ECPR2005_SchulzW_EfficacyParticipation.pdf

Showalter, P. H. (2001). Assessing the Level and Nature of Political Participation among Academic Librarians in North Carolina. Retrieved from https://cdr.lib.unc.edu/indexablecontent/uuid:8d8d9140$458 \mathrm{c}-4 \mathrm{c} 33-\mathrm{a} 5 \mathrm{f} 7-88 \mathrm{e} 091 \mathrm{dce} 4 \mathrm{~d} 8$

Sucgang, E. P. (2006). Typology and Correlates of Political Participation Among Filipinos. Philippine Journal of Psychology, 39(2), 31-65. Retrieved from https://www.scribd.com/document/329502904/Filipino-Political-Participation

Tam Cho, W. K., Gimpel, J.G. \& Wu, T. (2006). Clarifying the Role of SES in Political Participation: Policy Threat and Arab American Mobilization. Journal of Politics, 68 (4), 977-991. Retrieved from http://cho.pol.illinois.edu/wendy/papers/arabtime.pdf

Velasco, D. (n.d.). Rejecting 'Old-style' Politics?: Youth Participation in the Philippines. Retrieved from http://library.fes.de/pdf-files/bueros/philippinen/04526/countrypapers_philippines.pdf

Villarama, M. S., Jr. (2017). Culture of Delay. Retrieved on June 21, 2017 from http://ca.judiciary.gov.ph/index.php?action=mnuactual_contents\&ap=j6040

Xinzhi Zhang \& Wan-Ying Lin (2014). Political Participation in an Unlikely Place: How Individuals Engage in Politics through Social Networking Sites in China. International Journal of Communication, 8, 21-42. Retrieved from http://ijoc.org/index.php/ijoc/article/view/2003/1047 